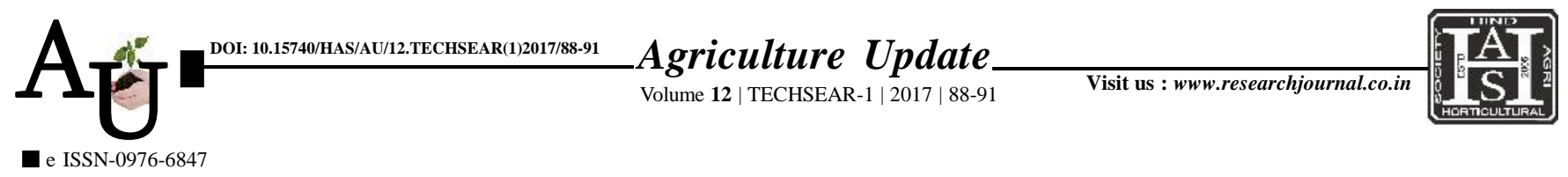

\title{
Research Article: Effect of NAA and IBA on stem cuttings of rose
}

\author{
C. KRISHNAMOORTHY, B. SUBHA SHREE AND B. SUVETHA
}

Article Chronicle: Received :

05.07.2017;

Accepted :

22.07.2017

KEY Words :

Rose, Cuttings, IBA, NAA, Growth parameters

Author for correspondence :

\section{KRISHNAMOORTHY}

Department of

Horticulture,

Vanavarayar Institute of Agriculture, POLLACHI

(T.N.) INDIA

Email:plantdoctorkrishna@ gmail.com

See end of the article for authors' affiliations

SUMMARY : A shade net experiment was conducted in Vanavarayar Institute of Agriculture, Pollachi, Tamil Nadu during 2016 - 2017 with an objectiveof determine the rose cuttings response to Auxins i.e. Indole butyric acid (IBA) and Naphthalene Acetic Acid (NAA) at 0, 500, 1000, 1500 and $2000 \mathrm{ppm}$ concentrations in growing media. Both had a significant effect on all sprouting and growth parameters. Maximum bud sprouting (78.8 \%), days to sprout (6), number of leaves / plant (10), chlorophyll index $(39.3 \mathrm{mg} / \mathrm{g})$ in rose cuttings were recorded at $1500 \mathrm{ppm}$ of IBA $\left(\mathrm{T}_{3}\right)$. The optimum level of IBA was found in the range of 1000 and $1500 \mathrm{ppm}$, while no such effect was evident of NAA. Of these, IBA was superior to NAA for its strongsynergistic effect on all growth parameters.

How to cite this article : Krishnamoorthy, C., Shree, B. Subha and Suvetha, B. (2017). Effect of NAA and IBA on stem cuttings of rose. Agric. Update, 12(TECHSEAR-1) : 88-91; DOI: 10.15740/HAS/AU/ 12.TECHSEAR(1)2017/88-91.

\section{BACKGROUND AND OBJECTIVES}

Rose, the queen of flowers, is favoured for its beauty and many other uses like production of petals, making rose oil (Attar), rose water, rose wine, rose marmalade (Gulkand), rose jam, rose crystallized petals, rose honey, extraction of perfumes, extraction of vitamin $\mathrm{C}$ from hips, for medicinal uses and for sale as cut flowers (Khan et al., 2004). In agriculture the production of plant species through sexual as well as vegetative means is of prime importance to continuity of generation.

Most of the plant species perpetuate through sexual method of propagation, which is easy and plays a vital role in the development of new species that are best suited to the changing environment. Each individual resulting from sexual reproduction usually has a unique combination of genes. There are scores of plant species that are not only hard to be propagated sexually but also show complexities and produce undesirable characters if propagated through sexual means (Lidwien et al., 2006 and Uma and Gowda, 2007). Vegetative propagation therefore, is the most vital and sole method to reproduce these plant species still having desirable characters (Sun and Chen, 1998). These plant species are propagated true to type from somatic cells through cutting, budding, grafting, layering etc. Among these the use of stem cuttings is the most easy and common method for growing roses (Anderson and Woods, 1999 and Costa and Challa, 2008).

The establishment and growth rate of cutting dependsupon many factors like season of cutting, age and portion of the branch, growth media, moisture and nutrient status. 